\title{
THE LEGEND OF THE TWELVE FRIDAYS IN THE RUSSIAN AND IRISH TRADITIONS: AN ATTEMPT AT CONTRASTIVE ANALYSIS
}

\author{
SERGEY V. IVANOV
}

\section{Introduction}

The very name of the Societas Celto-Slavica invites, in particular, discussion of some topics common to both Celtic and Slavic traditions. In this paper, I will focus on a text which is abundantly attested in every European language, paying special attention to its manifestations in Irish and Russian literature and folklore.

The Legend of the Twelve Fridays is an excellent example of a text whose history and development may be traced from the $11^{\text {th }}$ century to the modern day. Given such a remarkable longevity, it has many variants that are characteristic for a certain period or a certain region. The interrelationship of these variants is for the most part obscure, and thus every attempt at clarifying it adds to our understanding of their evolution.

The Legend was a very popular text in the Middle Ages, and its popularity has not ceased in the modern era. Despite, or perhaps due, to its wide dissemination, its origins remain enigmatic, for at least two reasons: firstly, it is relatively short (in the Western recensions), and obviously was regarded as too minor by scholars, who paid little attention to it; secondly, it enjoyed great popularity both in Western and Eastern Christianity, being preserved in a vast number of manuscript copies ranging from the $11^{\text {th }}$ to the $20^{\text {th }}$ centuries in various languages, which makes research and even the identification of different recensions a very complicated task.

The Western variants of the Legend are found in Latin as well as in virtually all vernacular European languages, including German, English, Swedish, Danish, Irish, Welsh, French, Spanish, Catalan, Occitan, and Italian. In the East, we have Slavic and Greek versions.

Alexander Veselovsky (1876) distinguished between two main versions of the Legend - Eleutherian and Clementine. The first of these is named after the lead character of the story which recounts the theological dispute between a certain 'Jewish philosopher' Tarasius and a 'Christian philosopher' Eleutherius. At the end of the conversation Tarasius acknowledges his defeat, but claims that the Christians do not know about

\footnotetext{
* This paper was written as part of the project 'The Legend of the Twelve Fridays in the Slavic and West European Traditions' funded by the Russian Foundation for Humanities (№ 13-0400062).
} 
twelve Fridays in the year on which one should fast to obtain a Heavenly reward. Afterwards Eleutherius learns this secret from Tarasius' son, and the text concludes with a list of the twelve Fridays. This version of the Legend is found only in Slavic manuscripts and need not concern us here since, as such, it has no parallels in any other traditions and the origin of this version is still unknown.

\section{Versions of the Legend}

I will deal, therefore, only with the Clementine version of the Legend. The Clementine variant is much shorter and lacks all the dispute story, consisting only of an enumeration of the Fridays and a very brief preamble and conclusion. The text, which is said to have been found by St Clement in the Canons and Acts of Apostles, promises to the faithful that after death their souls will be taken to heaven by angels, if they observe a strict fast on the twelve Fridays in the year which are then enumerated. I will refer to this variant as 'type A'. This version is attested in the Latin manuscripts as early as the $11^{\text {th }}$ century (Ivanov 2011).

However, the situation is even more complicated since there is one more text which is closely related to the Clementine version. This is the list of reasons for fasting on Fridays that explains the significance of each Friday by linking it with various events of the biblical history. This list can be found both in conjunction with the Legend of the twelve Fridays and as a separate unit. Henceforth, I will designate this variant as 'type B'.

To give just two early examples of each type, I reproduce below, for type A, the text from Biblioteca Medicea-Laurenziana, Plut. IV, sin., Cod. 4 (11 ${ }^{\text {th }}$ cent.) published by Fournier (1915), and, for the type B, the text from British Library MS Additional 34763 (late $14^{\text {th }}$ cent.) edited by Suchier (1910: 87).

Type A

Ego Clemente romanus pontifice, inveni in canones Apostolorum hoc quod Dominus dixit ad beatum Petrum Apostolum magister meus, de istis duodecim diebus Veneris quibus omne christianos debuit jejunare in pane et aqua usque ad vesperum. Duodecim apostoli sunt, duodecim dies Veneris sunt. Primus de mense martio; secundus ante Annunciatio sancte Marie; tertius Parasceven; quartus ante Ascensa Domini; quintus ante Pentecostes; sextus in quattuor tempora de mense junio; septimus ante missa sancti Johannis Baptiste; octavus ante festivitate sancti Petri; nonus post Natale Apostolorum; decimus primus, in mense September; undecimus, secunda ebdomada mense decembrio; duodecimus, ante Nativitatem Domini. Hoc sciatis, fratres et sorores, quia istis duodecim diebus observandi sunt usque ad vesperum in pane et aqua. Si istos dies observare poteritis, in exitus anime vestre accedunt angeli et ministrant vobis in vitam eternam. Amen. 


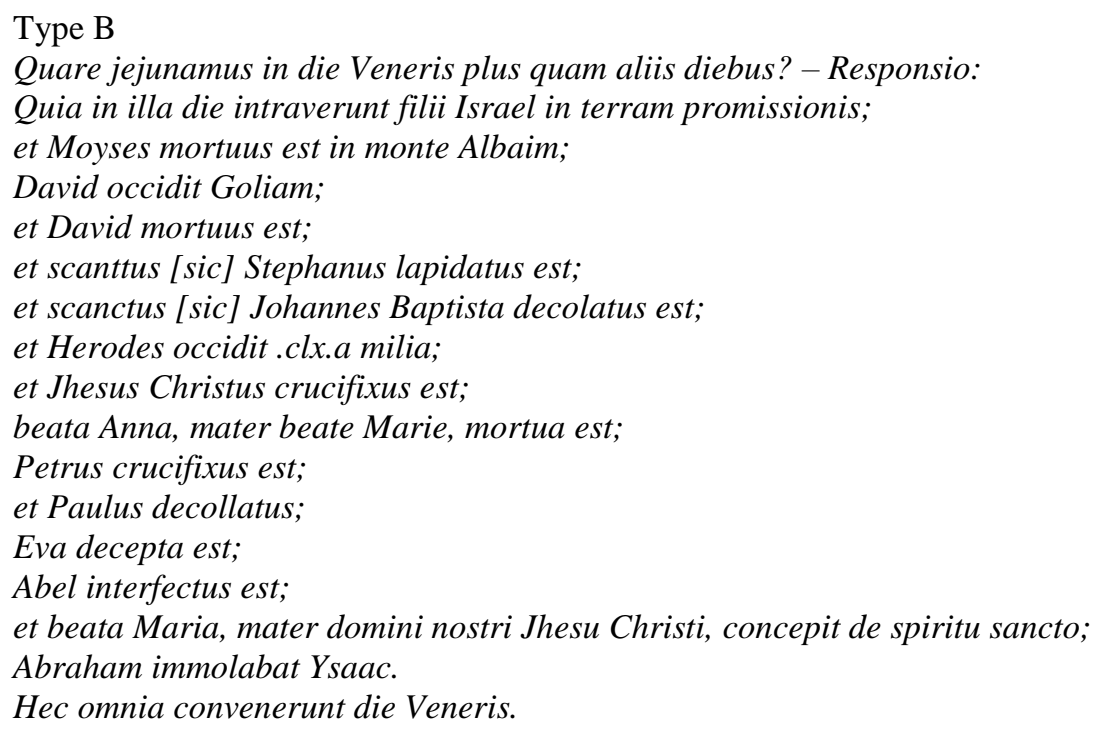

\section{Irish texts of Type A}

Only three Irish texts of the type A have been published: two of these are found in the same MS (RIA 24 P 25; Leabhar Chlainne Suibhne, 1513-1544) and were edited by Paul Walsh (1920: 120; hereafter 'W') and Gearóid Mac Niocaill (1958-61: 32-33; hereafter ' $M$ '); and another is found in British Library Cotton Appendix LI (1589) and was edited by Standish O'Grady (1926: 319; hereafter ' $G$ '). Below I reproduce these texts: ${ }^{\text {' }}$

(W) is iad so in da dubhaine deg ordha na bliadna i. in cedaine do marta ${ }_{7}$ an aoine reim Fheil Muire na Sanuise 7 aine in cesta ${ }_{7}$ an oine roim freasgabail 7 in aine na diagh ${ }_{7}$ in aoine roim cincis ${ }_{7}$ in aine [reim] feil San Seaan ${ }_{7}$ in aine roim feil Poil ${ }_{7}$ Pedair ${ }_{7}$ in aoine na diaigh ${ }_{7}$ in ced dubaine do mi medhoin in foghmair 7 darna dubhaine do mi medhoin in geimridh ${ }_{7}$ an dubhaine roim nodluic.

These are the twelve Golden Black Fridays of the year, namely, (1) the first Friday of March, (2) the Friday before the Feast of Annunciation, (3) Friday of the Passion, (4) the Friday before the Ascension, (5) the Friday after the Ascension, (6) the Friday before Pentecost, (7) the Friday before the Feast of St. John, (8) the Friday before the Feast of SS. Peter and Paul, (9) the Friday following the same, (10) the first Black Friday of September, (11) the second Black Friday of December, and (12) the Black Friday before Christmas. ${ }^{2}$

\footnotetext{
${ }^{1}$ Hereafter I give the texts as they stand in editions, in each case following the editorial principles used by their authors, although they sometimes vary significantly.

${ }^{2}$ Translated by Walsh (1920: 120).
} 
(G) Ocus atáit dá áine dég órda sa bliadain ocus gébé neach gnáitheochus a ndénam amaille haitrigi ocus re fáisidin eir arán ocus eir uisgi do réir Clemens pápa ní téid an tí sin a nitfearnn .i. [an cét ái]ne do márta. an dara háine an áine roim féil [m]ói[r] Muire na sanaisi. an treas áine an césda. an ceathramadh an áine ré freasgabáil. an cúigeadh ocus an tseiseadh an áine ré qinqís ocus na diaig. an tseachtmadh an áine roim féiltin Seaain. an tochtmadh ocus a náimeadh an áine roim Póil ocus na diaigh. an deichmeadh an cét áine do mí meadhoin an fómair. an taenmadh dég an dar[a áin]e do mí meadhoin an geimrid. an dara háiní dég [roim] nodlaig ocus is é baránta leighinn na náintedh so adubramair. Prima martis anut. par. as. ante. post pente. pre is. preque pauli post prima septembris secunda decembris.

In the year are also twelve Golden Fridays: the which whosoever uses to observe on bread and water, with confession and penance, that man (according to Pope Clement) enters not into Hell. They are these: 1. the first Friday in March 2. Friday preceding Great Lady-day of the Annunciation 3. Friday of the Passion 4. Friday before Ascension-day 5. and 6. Fridays before and after Quinquagesima 7. Friday before S. John's Day 8. and 9. Fridays before and after S. Paul's Day 10. first Friday in mid-autumn month [September, O'Grady erroneously October - S. I.] 11. second Friday in mid-winter month [December; O'Grady erroneously January - S. I.] 12. Friday before Christmas. The warrant for which doctrine of the Fridays that we have named being: Prima martis etc. ${ }^{3}$

(M) Clemens Pāpa fuair ōna espulaibh a fhis co fuilet dā aine dēc ōrda sa bliadhain, \& cidbē Christuighe do dēnu iat, mar scarus a anum re a corp, tecuit aingil do nim ina coinne, co mbertir a partus $[\bar{e}]$.

Pope Clement learned from the apostles that there are twelve golden Fridays in the year, and any Christian who observes them, when his soul leaves his body, the angels of heaven will come to meet it, and he will be taken to Paradise.

Then follows a list of twelve Fridays largely corresponding to that of G and W, and then the conclusion:

Ocus gach nech do gēna in dā Aīne dēc sin ar arān \& ar uisci, acht co mbeith fā breith \& fä fhaìsitin, tecuit aingil a coinne a anma \& $r l$.

And whoever observes these twelve Fridays on bread and water, provided that there are penance and confession, the angels will come to meet his soul etc. ${ }^{4}$

Then follows a verse version of this text which is a faithful paraphrase.

\footnotetext{
${ }^{3}$ Translated by O'Grady (1926: 319-20).

${ }^{4}$ Translated by the author.
} 
The main difficulty with the Irish texts is that they are still unpublished for the most part. The manuscript catalogues list more than twenty instances not considered so far. Thus, in the Library of Trinity College, Dublin, there are at least six manuscripts (numbers 1285, 1325, 1363, 1382, 1385, 1411) containing the Legend text (see Abbott and Gwynn 1921). In the Catalogue of Irish manuscripts in the Royal Irish Academy, at least fourteen instances of the Legend text can be found, mostly in the manuscripts of $18^{\text {th }}-19^{\text {th }}$ centuries, e.g. 23 M 29 (17-18 ${ }^{\text {th }}$ cent.), 23 K 24 (18 ${ }^{\text {th }}$ cent.), etc. Whitley Stokes (1907: 309) mentions among the contents of British Library Additional MS 30512 (the Book of O'Mulconry) a text on the twelve golden fasts in the year (fol. 52a) which, according to Robin Flower (1926: 496-7), agrees with the text edited by O'Grady. Gearóid Mac Niocaill (1958-61: 32) draws attention to a fragment of a related text in the library of Trinity College, Dublin MS H.2.10 (No. 1300 in Abbott and Gwynn's Catalogue), but this has not been edited.

The list of Fridays in the three published texts can be presented in the following table:

\begin{tabular}{|c|c|c|c|}
\hline & $\mathrm{M}$ & $\mathrm{G}$ & $\mathrm{W}$ \\
\hline 1 & $\begin{array}{l}\text { an cēd dubAīne don mī } \\
\text { Marta }\end{array}$ & [an cét ái]ne do márta & in cedaine do marta \\
\hline 2 & rē fēil Muire na Saindsi & $\begin{array}{l}\text { roim féil }[\mathrm{m}] \text { ói }[\mathrm{r}] \\
\text { Muire na sanaisi }\end{array}$ & $\begin{array}{l}\text { reim Fheil Muire na } \\
\text { Sanuise }\end{array}$ \\
\hline 3 & Aīne in Cēsta & áine an césda & aine in cesta \\
\hline 4 & rē Fresgabāil & ré freasgabáil & roim freasgabail \\
\hline 5 & rē Cengcighis & ré qinqís & na diagh [freasgabail] \\
\hline 6 & $\begin{array}{l}\text { rē nDomnach na } \\
\text { Trīnōide }\end{array}$ & na diaig [qinqís] & roim cincis \\
\hline 7 & rē fēil Eoin & roim féiltin Seaain & [roim] feil San Seaan \\
\hline 8 & rē fēil Petair \& Pōil & roim Póil & roim feil Poil ${ }_{7}$ Pedair \\
\hline 9 & in Aīne 'na diaid-sein & na diaigh [Póil] & $\begin{array}{l}\text { na diaigh }\left[\text { Poil }_{7}\right. \\
\text { Pedair] }\end{array}$ \\
\hline 10 & $\begin{array}{l}\text { in cēd dubAīne do Mī } \\
\text { Meodhoin in Fhogmair }\end{array}$ & $\begin{array}{l}\text { an cét áine do mí } \\
\text { meadhoin an fómair }\end{array}$ & $\begin{array}{l}\text { in ced dubaine do mi } \\
\text { medhoin in foghmair }\end{array}$ \\
\hline 11 & $\begin{array}{l}\text { in cēd dubAīne do Mī } \\
\text { Medōin an Gemrid }\end{array}$ & $\begin{array}{l}\text { an dar[a áin]e do mí } \\
\text { meadhoin an geimrid }\end{array}$ & $\begin{array}{l}\text { darna dubhaine do mi } \\
\text { medhoin in geimridh }\end{array}$ \\
\hline 12 & rē Nodluic & [roim] nodlaig & roim nodluic \\
\hline
\end{tabular}

As can be seen, these lists are virtually identical, apart from some minor discrepancies, such as Domnach na Trinōide in M: it is clear that the Friday before Trinity Sunday is the same as the Friday after Pentecost which is mentioned in G. The other difference concerns the fifth and sixth Fridays, 
which are, respectively, before and after Pentecost in $\mathrm{M}$ and $\mathrm{G}$, and after Ascension and before Pentecost in W. Additionally, it should be noted that W lacks the preamble which we find in $\mathrm{M}$ and $\mathrm{G}$.

As for the origin of these texts, they are certainly not an Irish invention. The Latin examples given above testify clearly that the Irish Fridays are based on a long and well-established tradition, and, most probably, on the Latin one, as the conclusion of G, where the Latin list of Fridays is given (Prima martis anut. par. as. ante. post pente. pre is. preque pauli post prima septembris secunda decembris), indicates. However, it well may be that the Irish texts were translated from different Latin sources, as is indicated by slight variations between them, and this prevents us from establishing a common prototype.

\section{Irish texts of Type B}

Type B, or dignatio diei Veneris, circulated both as a separate text, but also as a pendant to the Twelve Fridays text, forming a more elaborate version of the Legend. This form of the Legend became widespread in vernacular recensions, especially in Italian and French, but also in Old English. ${ }^{5}$ It is difficult to say whether Type B had an independent origin and was later attached to the Twelve Fridays Legend or whether it arose as an explanatory addition, which at some stage began to be transcribed as a single unit. So far four Irish texts of the dignatio diei Veneris have been published. One of these was edited by Douglas Hyde (1906: 218-9) from a manuscript in his private possession, 'written by one of the O'Gormans'. The second text was published by Torna (1912: 107) from the Royal Irish Academy MS 23 M 30 (17 ${ }^{\text {th }}$ cent.). The next attestation comes from Bibliothèque Nationale de France MS Fonds Celt., no. 1 (late $15^{\text {th }}$ cent.) edited by Henri Gaidoz (1888-9: 133-5). And, lastly, there is an account of events that happened on Friday in the poem on the Works of the Sixth Day (Carney 1969), preserved in the $14^{\text {th }}$-cent. National Library of Ireland MS G 3, though the portion containing this text is written 'in a $15^{\text {th }}$ century hand' (ibid., 148). Once again, it should be stated that many Irish manuscript sources still remain unpublished. The indexes to the Catalogue of Irish manuscripts in the Royal Irish Academy list more than ten instances of this type of text, for example in the MSS 3 B 38 and 23 C 30.

This type of the Legend also has many parallels in the Latin and vernacular traditions, but, in these cases, we cannot be certain that the Irish versions go back to a Latin original, as opposed to some vernacular versions. In any event, the Works of the Sixth Day seems to be the earliest example of Type B in Irish. It must be stressed that the first attestation of this type comes

\footnotetext{
${ }^{5}$ An Italian version was published from the late $14^{\text {th }}$-century MS Biblioteca Corsiniana, Rossi 30 (44.C.5) by Girolamo Amati (1866: 5-7). The French variants can be found in Louis Moland (1862: 104) and Paul Meyer (1883: 96-97). On the dignatio in general and on an $11^{\text {th }}$-cent. Old English example, see Lees (1986).
} 
not from the Latin but from the Old English text, namely, from a homily for Easter found in an $11^{\text {th }}$-century manuscript (Cambridge, Corpus Christi College 162 F; see Lees 1986: 115-142). However, since, as we will see, type B does not occur in the Russian tradition, I reproduce below only one example (that edited by Hyde 1906: 218-9):

\section{Dia h-Aoine}

Dia h-Aoine do pheacaigh Adhamh,

Dia h-Aoine do cuireadh ar Phárrthas amach é,

Dia h-Aoine do h-iadhadh neamh ${ }_{7}$ fosgladh ifrionn

Dia h-Aoine do mharb Cáin Abel,

Dia h-Aoine do cuireadh an díle tar an domhan,

Dia h-Aoine do cuireadh clanna Israel tre'n Mhuir Ruaid,

Dia h-Aoine do ceusadh Críost,

Dia h-Aoine do rinneadh dris ${ }_{7}$ draighne, agus gach luis mín i dtalamh,

Dia h-Aoine do cuireadh Stephán chum báis,

Dia h-Aoine do mharbh Herod na leinbh i n-uimhir 4020,

Dia h-Aoine do crochadh Peadar agus Pol,

Dia h-Aoine do baineadh a cheann d'Eóin Baiste,

agus dia h-Aoine tugadh toradh do'n talamh.

On Friday

On Friday Adam sinned,

On Friday he was sent out of Paradise,

On Friday heaven was closed and hell opened,

On Friday Cain killed Abel,

On Friday the flood was sent upon the world,

On Friday the children of Israel were sent through the Red Sea,

On Friday Christ was crucified,

On Friday briars and thorns were made and every smooth herb in ground,

On Friday Stephen was put to death,

On Friday Herod killed the children to the number of 4020,

On Friday Peter and Paul were crucified,

On Friday his head was taken off John the Baptist,

And on Friday fruit was given to the ground.

The last and the most important evidence to be discussed is a text from 'an old Irish manuscript volume which was written in English on a blank page by a person named Timothy Denaher' (Lenihan 1868). It enumerates twelve Fridays and prescribes that a definite number of prayers be said for each Friday in commemoration of some biblical events. The 'old manuscript' may well be the $18^{\text {th }}$-cent. British Library MS Additional 31877 (see Flower 1926: 215), which contains two versions of the Legend, an Irish and an English one 
(ibid., $\S \S 11,17)$. This identification was already suggested by Suchier (1910: 173-4). The English text reads as follows:

The Golden Fridays of the year

Whosoever fasteth on the Golden Fridays, and eats but one meal of bread and water each Friday, and prays devoutly on each of them days as followeth shall have five gifts.

First, he shall not die a sudden death, nor he shall not die without the holy rites of the church; nor the devil will have power over him. He shall see the glorious Virgin Mary with his own corporeal eyes before his death; he shall see Our Lord Jesus Christ on the cross forty days before his death.

1. The Friday after the first Sunday in Lent to fast and say three Pater Nosters in honour of the Holy Trinity.

2. The Friday before the Annunciation of the Blessed Lady, which is the 25th of March, and to say twelve Pater Nosters in honour of the twelve Apostles. 3. On Good Friday to say fifty-two Pater Nosters in honour of the Crown of Thorns.

4. The Friday before Ascension Day to say forty Pater Nosters in honour of the forty days that our Saviour fasted.

5. The Friday before Pentecost to say thirty Pater Nosters in honour of the Holy Ghost.

6. The Friday after Pentecost to say twelve Pater Nosters in honour of the twelve Apostles.

7. The Friday before St John the Baptist to say thirty-three Pater Nosters in honour of our Lord's Passion.

8. The Friday before SS. Peter and Paul to say fifty-three Pater Nosters in honour of Jesus Christ.

9. The Friday before the first day in harvest, to say four Pater Nosters in honour of our Saviour's hands and feet.

10. The Friday before the second Lady Day, in harvest, to say five Pater

Nosters in honour of the five wounds of our Saviour.

11. The Friday before All Saints five Pater Nosters in honour of five

Apparitions of our Saviour after his resurrection.

12. The Friday before Christmas to say Pater Noster in honour of the Tokens that will come before Doomsday.

\section{The Russian parallels}

This text has many parallels on the Continent, as the German example demonstrates (Reiter 1907), but the most interesting point which brings us closer to the topic of this paper is that there are many similar texts in the Russian tradition. The Clementine version, the only version which concerns us here, is attested in Russian manuscripts from the $18^{\text {th }}$ century onwards and these texts were still being transcribed and reproduced in the countryside until recently. I have seen such a text in a notebook dated to the late 1960s. 
Evidence of its great popularity is the fact that I have found 53 copies of this text in the collection of the Institute of Russian Literature (Pushkin House) alone. The typical Russian variant of the Legend can be exemplified with the following text:

Collection of the Institute of Russian Literature (Pushkin House), Perets' Collection, no. 651 (18 ${ }^{\text {th }}$ cent.)

Поучение святаго папы римскаго о временных пятницах

1я пятница. На первой недели Великаго Поста: кто сию пятницу постится, тот человек от незапной смерти избавлен будет.

2а пятница. Пред Благовещением Пресвятыя Богородицы: кто сию пятницу постится, тот человек от убиения избавлен будет.

Зя пятница. На страшной недели Великаго Поста: кто сию пятницу постится, тот человек великой скудости и убожества сохранен будет.

4я пятница. Пред Вознесением Господним: кто сию пятницу постится, тот человек от потопу сохранен будет.

5я пятница. Пред Сошествием Святаго Духа: кто сию пятницу постится, тот человек от великаго греха сохранен будет.

6а пятница. Пред Илеею Пророком: кто сию пятницу постится, тот человек от убиения громоваго сохранен будет.

7я пятница. Пред Рождеством Иоанна Предтечи: кто ту пятницу постится, тот человек от вели греха избавлен будет.

8я пятница. Пред Успением Пресвятыя Богородицы: кто сию пятницу постится, тот человек от трясовицы сохранен будет.

9я пятница. Пред Рождеством Богородицы: кто сию пятницу постится, тот человек без покая не умрет.

10я пятница. Пред Архистратигом Михайхлом: кто сию пятницу постится, того человека имя написано будет у Господа в животных книгах.

11я пятница. Пред Рождеством Христовым: кто сию пятницу постится, тот человек при смерти узрит Пресвятую Богородицу.

12я пятница. Пред Богоявлением Господним: кто сию пятницу постится, тот человек написан будет у Господа в животных книгах.

Всегда ныне и присно и во веки веком аминь

The instruction of a holy Roman pope on the seasonal ${ }^{6}$ Fridays

$1^{\text {st }}$ Friday in the first week of the Lent: whoever fasts on this Friday, that man will be saved from a sudden death.

$2^{\text {nd }}$ Friday before the Annunciation of the Holy Virgin: whoever fasts on this Friday, that man will be saved from killing.

\footnotetext{
${ }^{6}$ A difficult point in translation since the Russian word 'временный' applied to Fridays may be a recollection of an earlier tradition going back to the Western Quattuor Tempora fasts, see Ivanov 2013a. Therefore I am unsure which translation would fit better: 'seasonal' as a reference to the seasonal fasts, or 'temporary', which would be more neutral, but no clearer in this context.
} 
$3^{\text {rd }}$ Friday in the Holy Week of the Lent: whoever fasts on this Friday, that man will be saved from great poverty and wretchedness.

$4^{\text {th }}$ Friday before the Ascension of Our Lord: whoever fasts on this Friday, that man will be saved from drowning.

$5^{\text {th }}$ Friday before the Day of the Holy Spirit (Whit Monday): whoever fasts on this Friday, that man will be saved from great sin.

$6^{\text {th }}$ Friday before Elijah the Prophet: whoever fasts on this Friday, that man will be saved from thunder.

$7^{\text {th }}$ Friday before the Feast of John the Baptist: whoever fasts on this Friday, that man will be saved from great sin.

$8^{\text {th }}$ Friday before the Dormition of Our Lady: whoever fasts on this Friday, that man will be saved from fever.

$9^{\text {th }}$ Friday before the Nativity of Our Lady: whoever fasts on this Friday, that man will not die without confession.

$10^{\text {th }}$ Friday before St Michael's Day: whoever fasts on this Friday, that man's name will be written in the Lord's book of life.

$11^{\text {th }}$ Friday before Christmas: whoever fasts on this Friday, that man will see the Holy Virgin on his deathbed.

$12^{\text {th }}$ Friday before the Epiphany of Our Lord: whoever fasts on this Friday, that man will be written in the Lord's book of life.

Now and forever and to the ages of ages. Amen. ${ }^{7}$

\section{Conclusion}

The comparison of the Russian and Irish texts quoted above shows that, despite some similar features, there are also significant differences. First of all, regarding the list of Fridays, it should be noted that in the Russian text the feasts to which the Fridays are tied are prominent in the Eastern Church calendar. For example, such feasts as the Feast of Elijah the Prophet, the Dormition of Our Lady and the Epiphany play a much more prominent role in the Eastern liturgical year than in the Western one. But, of course, it is only natural that the realities of a particular region are reflected in a local popular tradition. More significantly, this text ascribes a specific reward for each Friday, and this differentiates it from all the variants I have referred to above. However, it can be compared with the introduction to the Hiberno-English text quoted above, which promises to the faithful particularly that he shall not die a sudden death, that he shall not die without the holy rites of the church, that he shall see the glorious Virgin Mary with his own corporeal eyes before his death. Three of these five gifts have their exact parallels in the rewards attested in the Russian example (rewards for the first, ninth and eleventh Fridays).

Of course, it would be awkward to compare the Russian material directly with the Irish. Nevertheless, I am sure that we should look for the origins of this specific Russian variant in the Western tradition, since it is

\footnotetext{
${ }^{7}$ Translated by the author.
} 
clearly a late development, with no detectable Russian or Slavic background (see Ivanov 2013b). Returning to the title of my paper, I can say that I used the word 'contrastive' not in the sense that between various versions of the Legend in various languages and traditions a common prototype or some genetic relationship in general cannot be established; rather I wished to emphasize the crucial point that there are so many forms, recensions, and types of this Legend that we inevitably come across one or more parallels to each of these forms in virtually any pair of local traditions. Much remains to be done in order to collect, publish and categorize the extant material. One of my aims was to present a brief survey of the Irish tradition, something which required abundant citations from the edited sources. I think, however, that such a descriptive approach at this stage of research may be of some use since it outlines the picture. And, hopefully, one day it will be possible to make the further step towards a comprehensive analysis of all the branches of this complex phenomenon.

Institute for Linguistic Studies, RAS, St. Petersburg

\section{References}

Abbott, T.K., Gwynn, E.J., 1921, Catalogue of the Irish Manuscripts in the Library of Trinity College, Dublin, Dublin/London.

Amati, G., 1866, Ubbie, ciancioni e ciarpe del secolo XIV (Scelta di curiosità letterarie inedite o rare dal secolo XIII al XVI, 72), Bologna.

Carney, M., ed., 1969, 'The Works of the Sixth Day', Ériu 21, 148-66.

Flower, R., 1926, Catalogue of Irish Manuscripts in the British Museum, London, Vol. II.

Fournier, P., 1915, 'Un groupe de recueils canoniques italiens des $\mathrm{X}^{\mathrm{e}}$ et $\mathrm{XI}^{\mathrm{e}}$ siècles', Mémoires de l'institut national de France, Académie des Inscriptions et Belles-Lettres 40, 95-213.

Gaidoz, H., 1888-9, 'La recommandation du vendredi', Mélusine 4, 133-5.

Hyde, D., 1906, The Religious Songs of Connacht. A Collection of Poems, Stories, Prayers, Satires, Ranns, Charms, etc., London, Dublin, Vol. II.

Ivanov, S.V., 2011, 'The Legend of Twelve Golden Fridays in the Western Manuscripts. Part I: Latin', in: Bondarko, N. A., Kazanskij, N. N., eds., Colloquia classica et indogermanica V, Acta linguistica Petropolitana 6.1, St Petersburg, 561-72.

Ivanov, S.V., 2013a, 'The Legend of the Twelve Fridays and Quattuor Tempora', in: Allen, P., Baranov, V., and B. Lourié, eds., Patrologia Pacifica Tertia: Selected Papers presented at the Seventh Asia-Pacific Early Christian Studies Society Annual Conference (Luce Center, Presbyterian College and 
Theological Seminary, Seoul, South Korea, July 5-7, 2012), and Other Patristic Studies, Scrinium, 9, Piscataway, N.J.: Gorgias Press, 2013, 185-206.

Ivanov, S. V., 2013b, 'Восточнославянская “климентовская” редакция "Сказания о 12-ти пятницах": к вопросу о происхождении и эволюции текста' [The East-Slavic "Clementine" Recension of the "Legend of the 12 Fridays": Towards the Text Origins and Evolution], in: Indo-European Linguistics and Classical Philology 17. Materials of the Annual Conference in Memory of Iosif Tronskij, held 24-26 of June 2013 at the Institute for Linguistic Studies, St. Petersburg, 318-42.

Lees, C.A., 1986, 'Theme and Echo in an Anonymous Old English Homily for Easter', Traditio 42, 115-42.

Lenihan M., 1868, 'Prayer Found in the Tomb of Our Saviour', Notes and Queries: Medium of Inter-communication for Literary Men, General Readers: 4th Series, 2, 330.

Mac Niocaill, G., 1958-61, 'Na haointe órga', Éigse 9, 32-3.

Meyer, P., 1883, 'Notice du Ms. A 454 de la Bibliothèque de Rouen', Bulletin de la Société des anciens textes français 9, 76-111.

Moland, L., 1862, 'Calendrier français du treizième siècle. D'après les manuscrits 283 lettr.fr. de la bibliothèque de 1'Arsenal, 7851 et $7019^{3}$ fonds français de la Bibliothèque impériale', Revue archéologique (nouvelle série) 5 , 89-104.

Mulchrone, K., O'Rahilly, T.F., FitzPatrick, E., Pearson, A.I., eds., 19261970, Catalogue of Irish manuscripts in the Royal Irish Academy, 8 vols, Dublin: Royal Irish Academy.

O'Grady, S.H., 1926, Catalogue of Irish manuscripts in the British Museum, London, Vol. I.

Reiter, K., 1907, 'Die zwölf goldenen Freitage', Zeitschrift des Vereins für Volkskunde 17, 449-50.

Stokes, W., 1907, 'The Fifteen Tokens of Doomsday', Revue celtique 28, 30826.

Suchier, W., 1910, L'enfant sage: Das Gespräch des Kaisers Hadrian mit dem klugen Kinde Epitus, Gesellschaft für romanische Literatur 24, Dresden.

Torna [Tadhg Ó Donnchadha], 1912, 'An tAthair Eóghan Ó Caoimh: a Bheatha agus a Shaothar', Gadelica: A Journal of Modern Irish Studies 1.2, 101-11.

Veselovsky, A.N., 1876, 'Опыты по истории развития христианской легенды. IV. Сказание о 12-ти' [Essays on the History of the Development of the Christian Legend, IV: Narration on the 12 Fridays], Журнал министерства народного просвещения [The Journal of the Ministry of National Education] 185, 326-67.

Walsh, P., 1920, Leabhar Chlainne Suibhne. An Account of the Mac Sweeney Families in Ireland, with Pedigrees, Dublin. 